Abstracta Iranica Abstracta Iranica

Revue bibliographique pour le domaine irano-aryen

Volume 24 | 2003

Comptes rendus des publications de 2001

\title{
Suhrawardî d'Alep. Intr. par Ch. Jambet, Paris, Fata Morgana, 2001, 85 p.
}

\section{Pierre Lory}

\section{(2) OpenEdition}

1 Journals

\section{Édition électronique}

URL : http://journals.openedition.org/abstractairanica/34570

DOI : 10.4000/abstractairanica.34570

ISSN : 1961-960X

Éditeur :

CNRS (UMR 7528 Mondes iraniens et indiens), Éditions de l'IFRI

\section{Édition imprimée}

Date de publication : 15 mai 2003

ISSN : 0240-8910

\section{Référence électronique}

Pierre Lory, "Suhrawardî d'Alep. Intr. par Ch. Jambet, Paris, Fata Morgana, 2001, 85 p. », Abstracta Iranica [En ligne], Volume 24 | 2003, document 185, mis en ligne le 05 janvier 2010, consulté le 25 septembre 2020. URL : http://journals.openedition.org/abstractairanica/34570 ; DOI : https://doi.org/ 10.4000/abstractairanica.34570

Ce document a été généré automatiquement le 25 septembre 2020.

Tous droits réservés 


\section{Suhrawardî d'Alep. Intr. par Ch. Jambet, Paris, Fata Morgana, 2001, 85 p.}

Pierre Lory

Cette réédition d'un texte de Corbin sur Suhrawardī publié en 1939 par la Société d'Etudes Iraniennes ne fait pas double emploi avec les autres études, beaucoup plus volumineuses, que le chercheur français a consacré au Maître de l'Illumination. Texte synthétique, ramassé, il traduit l'essentiel de ce qui nous est connu de la vie et des attitudes philosophiques de Suhrawardĩ. Dans sa dense introduction intitulée « Le guide intérieur ", Christian Jambet souligne ce que ce texte précis doit à la vision du soufisme de Louis Massignon, à l'accent mis sur la figure de Ḥallāj. Il le situe sur la courbe personnelle de Corbin lui-même, dont les présentations de l'išrāq comme la pensée d'un Ibn 'Arabī évoluèrent dans les années qui suivirent.

\section{INDEX}

Thèmes : 9. Philosophie

\section{AUTEURS}

PIERRE LORY

EPHE - Paris 